https://doi.org/10.24101/logos.2017.10

Gauta 20170128

VILIJA TARGAMADZE்

Vilniaus universitetas, Lietuva

Vilnius University, Lithuania

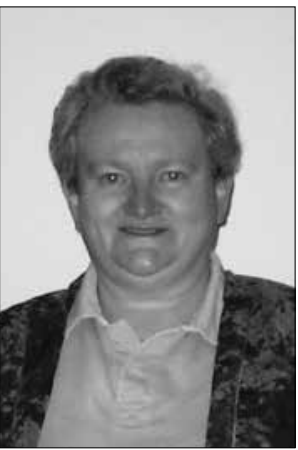

\title{
VERTYBĖS SAMPRATOS TURINIO ERDVE் IR JOS REIKŠMĖ ASMENS GYVENIME IR VALSTYBĖS POLITIKOJE
}

\author{
The Content Space of the Value concept and its Significance \\ in Personal Life and State Policy
}

\begin{abstract}
SUMMARY
Values are important in human and public life but their concept and significance are understood and interpreted differently, as this greatly depends on the methodological approach. The purpose of the article is to highlight the multidimensionality of the concept of value and its significance to the individual and state policy. To achieve this goal, theoretical analysis is integrated with the results of a study conducted in 2016. It appears that although each informant interprets the content of values individually, they are undoubtedly important in personal life and state policy. They can be given different degrees of weight, idiosyncratic interpretations and levels of significance for human life and state policy, but nonetheless, the moral basis of their evaluation is the reliability of virtue ethics. Thus, values and virtues are closely interrelated and the human and state policy navigation systems should be developed on the basis of virtues and closely related values.
\end{abstract}

\section{SANTRAUKA}

Vertybės yra svarbios žmogaus ir valstybės gyvenime, tačiau jų samprata ir reikšmė yra skirtingai suprantamos ir interpretuojamos. Tai priklauso nuo metodologinès prieigos. Straipsnio tikslas - išryškinti vertybiu sampratos daugiaaspektiškumą ir jų reikšmingumą asmens gyvenime ir valstybės politikoje. Tuo tikslu šalia teorinių samprotavimų pasitelkiamas ir 2016 m. atliktas tyrimas. Aiškejja, kad nors visi informantai savitai interpretuoja vertybių turini, jie neabejoja vertybių svarba asmeniniame gyvenime ir valstybès politikoje. Vertybėms gali būti suteikta skirtinga svarba, pateikta savita jų interpretacija ir reikšmės vertinimas žmogaus gyvenime ir valstybės politikoje, tačiau kiekvienu atveju moralinis vertybių vertinimo patikimumas yra dorybių etika. Tad vertybės ir dorybės sąryšingos - žmogaus ir valstybės politikos navigacinė sistema turètų būti kuriama dorybių ir su jomis susaistytų vertybių pagrindu. 
$\mathrm{V}$

ertybės - toks kasdienis mūsų gyvenimo vedlys, kad neretai giliau apie jas nesusimąstome. $\mathrm{O}$ iš tiesų jos yra mūsų gyvenimo alfa ir omega. Juk vertybès - kultūros ir ugdymo, valstybinès politikos, žmogaus gyvenimo ir pan. pagrindas. Pasak M. Lukšienès (2000, 24), žmogus yra „kaip aukščiausia vertybė ir ieškoma visų galimų būdų jo individualybei skleistis kultūros vertybiu kontekste". O ta kultūra juk yra ir tautos, ir valstybès, ir politine, ir ugdymo, etc. Apskritai vertybių reikšmę sunku pervertinti. Tik retokai jas žmogus ir visuomenė ar jos grupė reflektuoja. O priežastys, matyt, gana subjektyvios: laiko stoka, vertybinė sumaištis, kurioje patogiau nesirausti, susitelkimas i artimuosius ir / ar materialiuosius tikslus etc. Galima galbūt sąlygiškai nurodyti ir objektyvias priežastis, pavyzdžiui, ìstatymai ir poịstatyminiai dokumentai, reguliuojantys visuomenès, organizacijos, asmens poelgius, veikla, ar religiniai postulatai ir t. $t$. Bet čia vèl reliatyvu - istatymus ir poicstatyminius dokumentus rengia ir tvirtina žmonès, neišvengiantys subjektyvaus požiūrio; religijas praktikuojantys žmonės kartais labai jau savitai interpretuoja postulatus ir dogmas. Apskritai ver- tybès tampa individo, grupės, organizacijos ir pan. svarbia atskaitos ir rezultato siekimo dimensija. Šiame kontekste noriu atkreipti dèmesi i I. Jurgenos (2005, 50) pastaba, kad visada dera atkreipti dèmesi i dorini vertybių aspektą. Išties šis požiūris neretai ignoruojamas. Pasak A. Szerląg $(2016,112)$, neretai neįvertinamas vertybių supratimas kultūros sąveikų kontekste.

Vertybès buvo tirtos ir tebetiriamos ìvairiais požiūriais. V. Aramavičiūtè (2016), apibendrindama savo ilgalaikius tyrimus aksiologijos srityje, nurodo, kad vertybes galima interpretuoti ivairiais požiūriais: filosofiniu, sociologiniu, psichologiniu, edukologiniu. Vertybiu tyrimas nèra paprastas klausimas, tai priklauso nuo metodologinès prieigos, gebejjimo suprasti vertybių turinio erdvę etc.

Tačiau nè viename tyrime neteko aptikti, kad vertybės būtų nagrinejjamos ne tik teoriniu požiūriu, - Lietuvoje įvairių sričių atstovų (filosofuc, edukologuc, sociologu, politologu, kultūrologų ir pan.) klausiama apie jų vertybių sampratą ir reikšmę. Straipsnyje išryškinsime vertybių sampratos daugiaaspektiškumą ir ju reikšmę asmens gyvenime ir valstybès politikoje informantų požiūriu.

\section{VERTYBIŲ TURINIO LAUKO SUDĖTINGUMO IZŽVALGA}

Vertybės gali būti nagrinėjamos įvairių mokslų požiūriu, o šie dar turi savitas metodologines prieigas. Ju turinio sampratą dar komplikuoja, J. M. Halstead $(1996,12)$ nuomone, tai, kad „vertybės dažnai yra neišreiškiamos ir neartikuliuojamos, tad jas sunku ir analizuoti“. Be to, M. Warnock (1996, 46-47) teigimu, „kai kalbame apie vertybes arba tai, kas yra vertinga, tai paprastai darome viešuoju diskursu“ ir susiduriame su vertybiu realizmo problema. Taigi galimos ivairios vertybiu interpretacijos, jų reliatyvizmas ir pan. Bet kalbèti apie vertybes reikia, nes gyvenimas neigaus prasmès. Ir ne tik - tada jis „virsta beprasmiška 
Sizifo našta, kurios dažnai neįmanoma pakelti“ (Stoškus K., 1992, 3). Apskritai vertybe gali igauti ir didelę socialinę svarba, pavyzdžiui, pareiga gali būti suprantama kaip vertybè. Tačiau tai nèra taip paprasta. İsigilinkime i A. MacIntyre'o (2000, 181) minti:: „Kanto pareigos samprata yra tokia formali, kad jai galima suteikti bet koki turini, todèl kiekvienas, perpratęs Kanto pareigos sąvoka, perpranta konformizmą valdžios atžvilgiu." Šiame teiginyje galima ižzelgti ir turinio formalumo bei jo reliatyvumo aspekta, nesunkiai užpildomą reikiamu / norimu kieno nors atžvilgiu turiniu.

Vertybių sampratų ir klasifikaciju yra pakankamai daug, tai priklauso nuo tam tikro metodologinio požiūrio i jas, tad ivvairių mokslu pateikiamas vertybiu sampratas ir ju klasifikacijas nagrinèti tokios apimties darbe nebūtu tikslinga, tik norètųsi atkreipti demesi, kad anot B. Kuzmicko (2001, 60), ,,vertybès išreiškia ne tai, kas faktiškai yra, buvo ar ga- lètų būti, bet tai, kas turètu būti, net jeigu tai negali būti visiškai igyvendinama". Taigi tenka sutikti su V. Aramavičiūtès $(2016,20)$ teiginiu: „Vertybèms būdingas privalëjimo, ịpareigojimo momentas, kurio negalima išvesti iš realiu faktu.." Šitame kontekste reikšminga ir A. Jokubaičio $(2012,37)$ mintis: „Dalykas $\mathrm{x}$ turi didesnę vertę, palyginti su y.“ Tenka pripažinti, kad tokie svarstymai gali atsirasti susipainiojus ivvairiausiu vertybių teorijų ir sampratų gausoje, pametus metodologinius atskaitos taškus, o ypač isigalint ekonominiam požiūriui i vertybes, atmetant teologini ir metafizini požiūrius. Tada nebelieka absoliutaus požiūrio i̇ vertybes ir tegalima jas santykiškai palyginti.

Teoriniu svarstymų apie vertybes gausoje kyla klausimas: kaip vertybes supranta žmonės, kodèl jiems vertybės svarbios, ar, jų nuomone, vertybès reikšmingos valstybés politikoje? Toliau apie tai bus kalbama empirinio tyrimo įžvalgose.

\section{TYRIMO ORGANIZAVIMAS}

Kiekvieno žmogaus ar atskiru grupių vertybiu supratimas gali būti skirtingas ar bent jau savitas. Tad $2016 \mathrm{~m}$. lapkričio 5-6 d. buvo apklausti informantai: žinomas politinių laidų vedejjas, korespondentè (rašo apie politiką), krikščioniškų laidų kūrejas ir korespondentas (nesvetimi politiniai klausimai), politikos apžvalgininkas, politologas, politikas, mokslininkai (filologijos, filosofijos, edukologijos (ugdymo filosofijos ir švietimo kultūros), sociologijos), rašytojas, tautinių mažumų ir lietuviškos mokyklos vadovai (edukologijos moks- lai), dviejų didžiausių jaunimo organizacijų vadovai, negalią turinčių asmenu organizacijos atstovè, švietimo ekspertas, visuomeniškai aktyvus studentas ir dirbantis jaunimo atstovas. Informantai pasirinkti pagal tam tikrus kriterijus (kalbeję vertybiu klausimu, turintys pilietinę pozicija, socialini statusa, besidomintys politika, žinomi savo sluoksniuose ir visuomeneje aktyvūs, virtualiai su manimi bendraujantys). Iš viso pasirinkta dvidešimt vienas informantas. I klausimus atsakè dvidešimt vienas (kadangi trys informantai nepareiške 
savo nuomonès, tai iš sąrašo buvo pasirinkti kiti). Informantų buvo prašyta per tris dienas atsakyti $i$ tris klausimus: Kaip Jūs suprantate, kas yra vertybė? (Jūsų vertybės apibrèžimas.) Argumentuokite. Ar Jums svarbios vertybės? Ko- dèl? Kodèl vertybès svarbios valstybès politikoje?

Daugiau kaip pusė informantų nenorëjo, kad būtų nurodoma jų tapatybè, tad jų atsakymai buvo sunumeruoti pagal atsakymo laiką.

\section{VERTYBIŲ SAMPRATOS TURININĖS ERDVĖS SKLEISTIS}

Galima išskirti dvi vertybių sampratos kategorijas: 1.1. Vertybès siejamos su dorybėmis. 1.2. Vertybių sampratoje dorybės neminimos. Pirmosioms išskirtinos dvi subkategorijos:

1.1.1. Vertybès sąryšingos su krikščioniškomis dorybėmis. Pavyzdžiui, šešioliktas informantas nurodo: „Vertybes suprantu kaip pamata, ant kurio klojami mūsu, žmoniu, tarpusavio santykiai. Kokie šio pamato stulpai? Tai - dorovinès vertybès, arba dorybès: protingumas, teisingumas, tvirtumas, susivaldymas (pamatinès dorybès) ir tikejjimas, viltis, meilè (dieviškosios dorybès). Tikiu, kad šios dorybės yra prigimtinès, nekintamos, jungiančios ir vienijančios žmones. Priešingu atveju mes niekada nesusitartume, kas yra vertybès, kadangi kiekvienam žmogui, priklausomai nuo jo patirties, požiūrio, nuostatų ir kt. dalykų, atrodytų vis kitaip."

1.1.2. Vertybès nesiejamos su krikščioniškomis dorybėmis. Pavyzdžiui, aštuonioliktas informantas teigia, kad jam "žymiai svarbesnès yra dorybès, o ne vertybès. Nes dorybès nurodo ì kažką objektyvaus, tuo tarpu vertybès yra labai subjektyvu. Vertybė yra tai, ką aš vertinu labiausiai. Tai gali būti bet kas - draugystė, pinigai, prestižas, ištikimybè. Ver- tybė ištrina bet kokias hierarchijas ir padaro mane vieninteliu sprendeju."

Informantu, kurie, bent jau akivaizdžiai nesieja vertybių su dorybèmis, nuomonè suklasifikuota ị dvi kitas subkategorijas:

1.2.1. Vertybès akcentuojamos kaip moderniojo mąstymo kategorija, nurodanti tai, kas subjektyviai laikoma vertinga. Pavyzdžiui, aštuntojo informanto manymu, "mąstymas vertybėmis politikoje absoliučiai dera su demokratiniu pliuralizmu ir atmesta tiesos paiešku galimybe politiniame mąstyme" ; dešimtasis informantas teigia: „Vertybès yra kultūros (kūrybos) fenomenas, tad negaliu ju laikyti esamomis be manęs, šalia manęs, nedalyvaujant man jų kūrime. Vertybè visada yra tai, ko dar nèra, bet aš galiu sukurti. Turiu pats kurti tai, kas gali būti vadinama etinèmis, estetinèmis, religinèmis, pažintinėmis, politinėmis ir kitokiomis vertybėmis. Metaforiškai sakant, vertybė yra žmogaus tiltas (lieptas) tarp dabarties ir jos pasikeitimo."

1.2.2. Vertybès kaip asmeninès ar visuomeninès veiklos principas ar prioritetas. Ketvirtoji informantè: „Vertybè man - tai visų pirma sąmoningumas. Sąmoningas suvokimas, nusiteikimas, pripažinimas laikytis vienų ar kitų nor- 
mų, taisyklių. Savotiška moralinè siekiamybè. Vertybè - tai, dèl ko susitariame visuomenèje, priimtinumas. Pavyzdžiui, ištikimybè. Mano giliu i̇sitikinimu, vertybè - nèra duotybè, tai igyjama, gaunama, išmokstama, tam pasiryžtama. Išskirčiau bendražmogiškąsias vertybes ir tas, kurios būdingos atskirai nacijai, kraštui, gal net rasei. Vertybių skalè subjektyvi: kas vienam atrodo vertybė, kitam - tik mažareikšmis mažmožis." Šeštoji informantè: „Mano vertybès apibrèžimas: dalykai, kurie pagristi svarbiausiomis nuostatomis. Tai dalykai, susiję su labai svarbia patirtimi." Devintoji informantè: „Tai yra dalykai, kurie svarbūs tau nepriklausomai nuo kintančių aplinkybių ar kitų žmonių vertinimų, jie yra siekiamas tikslas ir padeda suabejojus ar pavargus, taip pat planuojant laiką ir kitus resursus."

Išanalizavus informantų pateikiamas vertybių sampratas, aiškejja, kad visi informantai vertybes supranta subjektyviai, interpretuoja jų turini vadovaudamiesi savo požiūriu, tačiau vertybès jiems yra svarbios, nes jomis vadovaujasi savo gyvenime. Kai kurie informantai vertybiu nesieja su dorybėmis, o kiti neįsivaizduoja vertybių be dorybių, nes jos informantui yra kaip vertybiu atskaitos taškas.

\section{VERTYBIŲ SVARBA ASMENINIAME GYVENIME IR VALSTYBE்S POLITIKOJE}

Atsakymai i̇ antrą klausimą „Ar Jums svarbios vertybès? Kodèl?" buvo įvairūs. Galima išskirti dvi kategorijas:

2.1. Asmeniškai reikšmingas kompasas (2.1.1. Vertybès tampa veiklos tikslo orientyru. 2.1.2. Vertybès - savo veiklos rezultato vertinimo ir isivertinimo atskaitos taškas). 2.2.1. Reikšmingumas visuomeniniu požiūriu (2.2.1. Vertybès kaip visuomenès pažangos akstinas. 2.2.2. Vertybès asmens ir visuomenès sąryšingumo požiūriu).

2.1.1. Septintoji informantè aiškiai ìvardijo, kad vertybės „svarbios, nes žmogus turi kažkuo vadovautis, tai savotiškas gyvenimo žemèlapis“; keturioliktoji teigè: „Manyje tèvų suformuotos / perduotos / idiegtos vertybès - tai mano kasdieninės veiklos pagrindas, jos skatina veikti čia ir dabar, planuoti bei kurti ateiti.“ Šešioliktas informantas: „Man tai svarbu dèl to, kad dorovinès vertybès yra tam tikras elgesio ir veiklos orientyras, padedantis kiekvienam mūsų būti savimi, dalintis, kurti autentiškus santykius. Esu tikras, kad tik tuomet įmanoma galimybè būti išklausytam, suprastam, padrąsintam ir pan. Ši galimybè sudaro prielaidas žmogaus augimui, o tai ypatingai svarbu švietimo srityje, kurioje aš dirbu." Septyniolikta informantè: „Taip. Manau, kad vertybès yra lyg pamatas, ant kurio statomas gyvenimas, ir kryptis, kuri parodo, kur link veikti / eiti. Tai kaip misija ir vizija."

2.1.2. Vertybiu kaip savo veiklos rezultato vertinimas ir isivertinimas atsispindi kai kurių informantų atsakymuose. Pavyzdžiui, antroji informantè: „Vertybès labai svarbios, nes padeda îsivertinti, vertinti, koreguoti savo ir kitų elgesi, numatyti pasekmes ir svarbiausia - 
oriai jaustis"; dvyliktasis informantas: „Man vertybės yra svarbios, nes jos leidžia, priimant tam tikrus sprendimus, neabejoti pasirinkimais. Vertybès leidžia pamatyti save supančioje aplinkoje, sužinoti, kas man yra svarbu ir kodèl“; tryliktasis informantas: „Man vertybès labai svarbios, kadangi jos lyg tam tikros nuorodos, kurių laikantis žinau, kada elgiuosi tinkamai besilaikydamas savo noru ir lūkesčių. Lygiai taip pat man svarbu, kad savo vertybèmis vadovautųsi ir kiti žmonès, su kuriais tenka bendrauti ir palaikyti asmeninius ar profesinius santykius, kadangi tada žinau, jog tie žmonès turi savo principus, kas jiems leidžia išlaikyti tvirtą savo poziciją ir nuomonę, o būtent toks principingumas man yra vienas iš svarbiausių aspektų dirbant bei tiesiog bendraujant."

Kitoje subkategorijoje vertybių reikšmingumas siejamas su visuomene.

2.2.1. Ketvirtoji informantè pabrèžè, kad „vertybès gyvenime yra labai svarbios. Jos turi dideli vaidmeni tiek individo, tiek visuomenès, kaip komunos, tautos, pažangai, raidai“; penktoji informantè akcentuoja žmogaus ir visuomenès sąryšingumą naudos požiūriu: „Vertybės man labai svarbios. Vertybių kupinas žmogus turtina mūsų visuomenę savo požiūriu, savo veiksmais, savo elgesiu, gerais darbais. Svarbu, kad tos vertybès teiktų naudą žmogui bei visuomenei."

2.2.2. Devynioliktas informantas: „Vertybès man svarbios, kaip ir kiekvienam žmogui, kuriam - prisimenant Platono „Valstybèje“" naudojamą analogiją svarbi jo siela ir valstybe.." Šeštoji informantè: „Man svarbios vertybès: šeima, santuoka, bendruomenè, nes tai mano buvimo su kitais forma."
Taigi, vertybės kiekvieno informanto gyvenime yra svarbios - informantų atsakymuose ju reikšmingumas gali būti orientuotas ị asmeni ar susietas su visuomene, tačiau kiekvienu atveju akcentuojama vertybiu svarba, nes tai yra kiekvienos veiklos stuburas (ašis).

Trečiuoju klausimu buvo siekiama išsiaiškinti, ką mano informantai apie vertybių reikšmę valstybès politikoje. Išryškèjo dvi kategorijos: 3.1. Vertybė kaip valstybės politikos prioritetas. 3.2. Politiko kaip asmens vertybės.

Galima išskirti dvi „vertybès kaip politikos prioriteto" subkategorijas: 3.1.1. Vertybè kaip veiklos tikslas. 3.1.2. Prioriteto suteikimas tikslui ne vertybiniu pagrindu.

Tai galima iliustruoti kelių informantú atsakymais. 3.1.1. Vertybè kaip veiklos tikslas. Pavyzdžiui, pirmasis informantas pabrèže: „Vertybès politikoje, kaip ir bet kurioje kitoje veikloje, garantuoja veiklos nuoseklumą. Kitaip veikla vyksta chaotiškai, kai vienas veiksmas ne sustiprina, o silpnina arba griauna kito veiksmo rezultatus. Tai visuomenei priimtinų prioritetų buvimas / nebuvimas"; tryliktas informantas: „Tik vadovaujantis vertybėmis galima išlaikyti savo veiklos principus ir, buitiškai tariant, „turèti stuburą" priimant sprendimus. Vertybès padeda laikytis nuoseklios darbo krypties ir nesimètyti i pašalines sritis ar nesvarbius klausimus."

3.1.2. Vertybès ir tikslo prioritetas. Antra informantè: „Politikoje vertybès svarbios, bet politika iš principo nèra vertybiška, todèl joje vertybès išsigimsta arba geriausiu atveju gudriai prisitaiko prie situacijų. Be to, politika elgiasi ne deontologiškai, o teleologiškai, taigi, pamina kai kurias vertybes vardan numa- 
tytų tikslų." Dešimtas informantas: „Šiandienejje politikoje vyrauja reliatyvistinis (kartais vadinamas ir postmodernistiniu) pagrindinių žmogaus kultūrinių vertybių interpretavimas, neigiama vertybiu hierarchija, ir tai labai kenkia humanistinei valstybės prigimčiai, iškreipia ją paverčia valstybę instrumentu korporacijoms, klanams, turtingiausioms pasaulio šeimoms valdyti žmones pagal savus modelius ir interesus." Aštuntas informantas: „Modernioje demokratinejje politikoje vertybès svarbios dèl keliu priežasčių. Viena vertus, kasdienëje vartosenoje piliečiai vertybemis nurodo visa, ką laiko principais ir idealais, t. y. pateikia vertybes kaip priešpriešą interesams. Santykyje su interesais vertybès iš tiesu svarbios, nes leidžia politiką grististi suvokimu (kad ir subjektyviu) to, kas laikoma gera / siektina / teisinga iš principo, o ne naudinga sau ar grupei. Kita vertus, vertybès ar, tiksliau, kalbëjimas apie jas politinei klasei reikalingas kaip fasadas, leidžiantis pasislèpti nuo pareigos ieškoti objektyviai teisingos moralinės tvarkos, kurią turètų îtvirtinti įstatymai, koks kad buvo klasikinės politikos tikslas."

Informantai akcentavo valstybès politikoje ir asmenybès savybes, tačiau dèl ju pateikimo savitumo i subkategorijas nepavyko suklasifikuoti.
3.2. Politiko kaip asmens vertybės. Ketvirta informantè: „Altruizmas, ištikimybè, pagarba, empatija, patriotizmas. Šios vertybès, mano nuomone, yra imperatyvios valstybės politikoje. Tačiau aš ypatingai išskirčiau vieną savybę, be kurios valstybès politika pasmerkta murkdytis korupcijos, intrigu, pavojaus valstybingumui pelkèje, - tai sąžiningumas. Sąžinè politikui - aukščiau už viską. Bent taip aš isivaizduoju vertybes politikoje ir valstybeje." Penktas informantas: „Kiekvieno politiko atsakomybè prieš Lietuvos žmones priklauso nuo jo turimų, suprantamų vertybių. Mano manymu, žmogus, turintis tokias vertybes kaip sąžinè, pareiga, pagarba, tolerancija, darbas, gali dirbti savo šaliai ir teikti naudą mūsų visuomenei. Vertybès valstybės politikoje yra labai svarbios: politikai turi vykdyti duotus pažadus rinkèjams, būti teisingi ir sąžiningi kitų žmonių atžvilgiu."

Vertybių akcentavimas valstybės politikoje yra reikšmingas, nes vertybių ivvardijimas sietinas su užsibrèžtais valstybinès politikos veiklos tikslais ir jų igyvendinimo matavimu. Tik tai turètu būti sietina su dorybèmis, nes vertybès gali būti nebūtinai formuluojamos doriniu pagrindu, tada galima pamesti moralinị kompasą.

\section{IŠVADOS}

Vertybių samprata priklauso nuo metodologinio požiūrio i jas. Kadangi vertybiu sampratų yra gausybe், tai neidentifikavus metodologinio atskaitos taško ir îsigalint ekonominiam požiūriui i vertybes, atmetant teologini ir metafizini požiūrius, atsiranda galimybè vertybes tik santykiškai palyginti su kitomis ver- tybėmis, nes nebelieka absoliutaus požiūrio ị vertybes. Tai moksliniu požiūriu nèra korektiška.

Vertybès gali būti įvairiai klasifikuojamos - tai priklauso nuo atskaitos taškų. Vertybėms galima suteikti skirtingą krūvị, turinio požiūriu jos gali būti savitai interpretuojamos, vertinama jų reikšmè 
žmogaus ir valstybès politikoje, jos gali būti netgi pastumiamos i paribì, tačiau moralinis jų vertinimo patikimumas yra dorybiu etika. Tad vertybès ir dorybès sąryšingos. Žmogaus ir valstybès politikos navigacinè sistema turètu būti kuriama dorybiuc ir su jomis susaistytų vertybių pagrindu.

Kiekvienas informantas savitai interpretuoja vertybes, atskleisdamas jų turinį: vieni vertybes sieja su (ne)krikščioniškomis dorybėmis, kiti jas vertina kaip žmogaus ar valstybinès politikos veiklos prioritetus, dar kiti mano, kad vertybès yra moderniojo mąstymo kategorija, kuri nurodo, kas subjektyviai vertinga. Iš esmės subjektyvų vertybių supratimą galima aptikti visuose atsakymuose, tačiau kiekviename ju išryškèja vertybių svarba žmogaus ir valstybės gyvenime.

\section{Literatūra ir nuorodos}

1. Aramavičiūtè, V., 2016. Vertybès ir ugdymas: tarp kaitos ir stabilumo. Vilnius: Vilniaus universiteto leidykla.

2. Halstead, J. M., 1996. Values and Values Education in Schools. Values in Education and Education in Values, ed. J. M. Halstead and M. J. Taylor. Bristol: Falmer Press, Taylor \& Francis, Inc., 3-14.

3. Jokubaitis, A., 2012. Vertybiu tironija ir politika. Vilnius: Vilniaus universitetas.

4. Jurgena, I., 2005. Audzināšanas ideju vēsturiskā attīstība in scientific conference material February 25-26, 2005. Society, Integration, Education. Rezekne: Rezeknes Augstskola, 50-56.

5. Kukla, A., 2000. Social Constructivism and the Philosophy of Science. New York: Routledge.

6. Kuzmickas, B., 2001. Laime, asmenybe, vertybès. Vilnius: Lietuvos teisès universitetas.
Valstybės politikoje ir žmogaus gyvenime vertybès tampa atskaitos tašku siekiant tikslo ir, jei tikslai formuluojami vertybiniu (ypač dorybių) pagrindu, tai galima projektuoti stabilią žmogaus gyvenimo ir valstybès politikos trajektorija, ir vice versa. Taigi vertybès - tai valstybès ir piliečio gyvenimo kompasas, padedantis jam orientuotis ir priimti sprendimus bei juos igyvendinti.

Vertybès sietinos su dorybèmis, nes tai suteikia dorini stuburą valstybės politikoje ir asmens gyvenime ir gali tapti valstybės ir žmonių sąryšiu stiprinant valstybingumą ir pilietiškuma, tai padeda išvengti savasties praradimo dažnai dinamiškoje ir chaotiškoje aplinkoje, todèl siekiant tvarios valstybès plètros susitarimas tarp îvairių visuomenès grupių vertybiniu pagrindu yra ypač svarbus.

7. Lukšienė, M., 2000. Jungtys. Vilnius: Alma littera.

8. MacIntyre, A., 2000. Trumpa etikos istorija. Doroves filosofijos istorija nuo Homero iki dvidešimto amžiaus. Vilnius: Charibdè.

9. Stoškus, K.,1992. Žmogaus savikūra. Vilnius: Mintis.

10. Szerląg, A., 2016. Cross-cultural orientations of young generation of Poles and Lithuanians axiological connotations in the context of interaction of cultures. Atomization or Integration? Transborder aspects of Multipedagogy, ed. J. Pilarska, A. Szerląg, A. Urbanek. Cambridge: Cambridge Scholars Publisching, 112-128.

11. Warnock, M., 1996. Moral Values. Values in Education and Education in Values, ed. J. M. Halstead and M. J. Taylor. Bristol: Falmer Press, Taylor \& Francis, Inc., 45-53. 